\title{
IIIIIII 創薬研究の新潮流29
}

創 薬

シリーズ(8)

\section{老化研究のためのモデルマウス 一老化促進モデルマウスを軸にして一}

\section{森 政之 ${ }^{1)}$, 樋口 京一 ${ }^{2)}$}

要約 : 世界的に高齢者人口の急速な増加が予測されて いる状況下，「健康で活動的な人生の期間を可能な限 り延長する」という医学研究の最終目標を達成するた めには，ヒトの “老化”の基本的なメカニズムの生物 学的理解, および, 老化に伴い発症する様々な “老化 関連疾患”の発症機序の医学的解明が重要な課題である. 老化促進モデルマウス (senescence-accelerated mouse :

SAM）は一群の近交系マウス系統で，このうち SAMP 系統は共通して促進老化と短寿命を呈する．同時に， 老化アミロイド症, 老年性骨粗鬆症, 学習・記憶障害 など，ヒトに類似した様々な老化関連疾患をそれぞれ の系統特異的に示すことから老化研究に有用なモデル 動物として広く利用されている. 本稿では SAM マウ スの特性，および SAM マウスを用いた基礎ならびに 応用研究の現状を紹介する。

\section{1. 老化研究の目的とモデルマウス}

老化は「時間に依存する蓄積性（cumulative），進行 性 (progressive), 内因性 (intrinsic), および心身に 有害性の (deleterious) 機能的, 構造的変化で, 通常 は生殖的に成熟した頃に現れ, 結局は死によって完結 するものである」と定義される，老化はさらにがん， 心疾患, 脳卒中, 糖尿病, 認知症, サルコペニア, 骨 粗鬆症などの様々な老化関連疾患の基盤となると考え られている. 世界的に高齢者人口の急速な増加が予測 されている状況下，「健康で活動的な人生の期間を可 能な限り延長する」という医学研究の最終目標を達成 するためには，(1)未だ不明な点が多いヒトの “老化” の基本的なメカニズムの生物学的理解, および, “老化 関連疾患”の発症機序の医学的解明，および, (2)そこ から得られたエビデンスに立脚した抗老化処方や薬剤 の開発が重要な課題である。しかしながら, ヒトの老
化経過を追跡するには数十年単位を要し, しかも個人 差が大きく解析が困難である. 個人差の一因は, 遺伝 的プロファイル, 環境要因, 生活習慣などの個人差に あると考えられる，そこで寿命が比較的短く，環境統 御や遺伝子改変が可能な酵母, 線虫, ショウジョウバ エ，マウスを含む様々な生物種が老化モデルとして使 用されている. これらの研究から, 生物種に進化的に 共通した老化制御分子・機構としてインスリン／IGF-I シグナルや mechanistic target of rapamycin (mTOR), サーチュインなどが明らかとされ，それらを標的とし た抗老化・健康寿命維持処方の開発と検証が進められ つつある(1). 一方，これらの分子経路も含めて様々 な生物学的機構には明らかな種差があり, 得られた データのヒトへの外挿には限界があることに留意すべ きである。

\section{SAM マウスの成り立ちと特性}

老化促進モデルマウス (senescence-accelerated mouse：SAM）は, AKR/J マウスと遺伝的へテロ性を もった未知のマウスとの不測の交雑が生じたマウスコ ロニーから, 活動性の低下, 脱毛, 眼周囲病変, 脊椎 前後彎増強，短寿命などの老化現象を若齢より呈する 個体が発見されたことを端緒として，そのマウスコロ ニーを起源として世代毎に寿命の短縮や老化度評点 （表 1）の加齢依存的な急速な増加を指標として選抜・ 交配を重ねて樹立された一群の近交系マウスである (2).この過程で, 老化アミロイドーシス, 老年性骨粗 鬆症, 加齢依存的な学習・記憶障害などの老化関連 病態の発症の有無を指標として系統としての分離が 進められた. 現在, 実験動物コマーシャルブリーダー から入手できるものとして SAMP1, SAMP6, SAMP8, SAMP10 が, さらに同一のコロニーに由来するが正常

キーワード : 老化, 老化関連疾患, マウス, 遺伝子

信州大学 学術研究院 先鋭領域融合研究群バイオメディカル研究所 ${ }^{1)}$ 先端疾患予防学部門 ${ }^{2)}$ 神経難病学部門 （ 于390-8621 長野県松本市旭 3-1-1）

E-mail: keiichih@shinshu-u.ac.jp＼cjkstart原稿受領日：2018 年 12 月 11 日，依頼原稿 
表 1 マウスの老化度評点付けの一例

\begin{tabular}{|c|c|c|c|c|c|c|c|}
\hline \multicolumn{8}{|c|}{ Animal No. 119-2 } \\
\hline \multicolumn{2}{|c|}{ Age (Month) } & 8 & 12 & 16 & 20 & 24 & 28 \\
\hline \multirow[t]{2}{*}{ Behavior } & Reactivity & 0 & 1 & 2 & 2 & 3 & 4 \\
\hline & Passivity & 0 & 1 & 1 & 2 & 3 & 4 \\
\hline \multirow[t]{4}{*}{ Skin } & Glossiness & 0 & 2 & 2 & 3 & 4 & 4 \\
\hline & Coarseness & 0 & 1 & 2 & 3 & 3 & 4 \\
\hline & Hair Loss & 0 & 0 & 0 & 1 & 2 & 2 \\
\hline & Ulcer & 0 & 0 & 1 & 1 & 2 & 2 \\
\hline \multirow[t]{4}{*}{ Eye } & Periophthalmic Lesion & 0 & 1 & 1 & 2 & 3 & 3 \\
\hline & Corneal Opacity & 0 & 1 & 1 & 1 & 2 & 2 \\
\hline & Ulcer of Cornea & 0 & 0 & 0 & 0 & 1 & 2 \\
\hline & Cataract & 0 & 0 & 0 & 0 & 0 & 0 \\
\hline Spine & Lordokyphosis & 0 & 0 & 1 & 2 & 3 & 3 \\
\hline \multicolumn{8}{|l|}{ Others } \\
\hline Total & & 0 & 7 & 11 & 17 & 26 & 30 \\
\hline
\end{tabular}

8 力月齢より 4 カ月毎に, 行動, 皮膚, 眼, 脊椎に現れる 11 項目の加齢変化を 5 段階 $(0,1 ， 2 ， 3 ， 4)$ で評点付けし, その合計をマウスの老化度評点とする。評点基準は客観性が保証されるよう厳密に規定されており，例えばGlossiness of skin の評点基準は $0=$ Natural gross, 1 = Decrease in gross, $2=$ Complete disappearance of gross, $3=$ Complete disappearance of gross and hair appears dirty, 4 = Complete disappearance of gross and hair appears very dirty である. 国際的に通用するよう全て英語で作成してある.

表 2 SAM マウス各系統の特徵的な形質

\begin{tabular}{|l|l|}
\hline \multicolumn{1}{|c|}{ 系統 } & \multicolumn{1}{|c|}{ 形質 } \\
\hline SAMP1 & $\begin{array}{l}\text { 老化アミロイドーシス, 免疫機能障害, 老年性聴覚障 } \\
\text { 害, 老年性肺過膨張 }\end{array}$ \\
\hline SAMP6 & 老年性骨粗鬆症, 潰瘍性大腸炎 \\
\hline SAMP8 & 学習・記憶障害, 情動障害, サルコペニア \\
\hline SAMP10 & 脳萎縮を伴う学習・記憶障害, 情動障害 \\
\hline
\end{tabular}

な老化プロファイルを示す SAMR1 がある.

SAMP系マウスには共通して正常な成長過程の後, 4〜6 カ月齢より現われ急速かつ不可逆的に進展する 老化，すなわち促進老化が認められる．寿命も有意に 短縮しており，コンベンショナル条件下で飼育された データによると，50\%生存日数は SAMP系（prone： 易発性) に扔いて平均 291 日で, SAMR 系 (resistant： 抵抗性）に扮ける 489 日と比較して約 40\%短縮してい る.一方, 老化アミロイドーシス, 老年性骨粗鬆症, 加齢依存的な学習・記憶障害, サルコペニアなどの老 化関連病態は系統特異的に認められる (表 2)。ヒトや マウスのような高等動物においては老化や老化関連疾 患の発症は様々な遺伝子と環境因子による複合的な影 響を受けていると考えられている，促進老化や老化関 連病態が数世代の選抜・交配によって SAM 系統内に 固定されたことは，これらの形質がそれぞれ複数の遺 伝子に規定されていることを強く示唆する.SAM マウ スにおいては，促進老化を背景とすることで老化関連
病態の原因遺伝子の効果が強調され, 発症も促進され ているものと想定される. 老化や老化関連疾患の発症 が単一遺伝子の変異に起因する他のモデルマウス （3-8）と比較して, SAM マウスはこの点においてヒト との類似性を示す.

\section{SAM マウスを用いた基礎ならびに応用研究 の現状}

SAM マウスは老化の生物学的機序の解明に加えて, 老化関連病態の発症機序の解明や予防法・治療法の研 究に広く用いられている. 以下にそのうちのいくつか を紹介する．SAM マウスを創薬に使用するメリット としては，(1)促進老化を示すがゆえに実験期間を短縮 できる点，(2)ヒトと類似した多因子性発症機序を有す る点, (3)特定の機序や遺伝子機能の効果が強調されて いるために, 薬剤の効果が現われやすい点などがある. 一方, デメリットとして, SAM マウスの促進老化や老 化関連病態の発症機序は特殊でヒトの正常老化とは異 なるためにヒトでの薬効が得られない可能性が想定 される。 また, SAMPマウスの促進老化・寿命や老化 関連病態の発症は飼育環境や食餌条件の違いで大きく 変化する.すなわち, 現在の適切な微生物学的統御や 温湿度管理などがなされた動物実験飼育室では SAMP マウスの促進老化が遅延され, 寿命も延びる傾向が明 確に認められる。 また，慨の組成によって，たとえば 後述する老化アミロイドーシスの発症や重篤度なども 
影響される。したがって, 異なる研究機関で得られた デー夕を比較する際には注意を要する。

\section{1）コエンザイム Q10 による促進老化遅延のメカニズ}

\section{么研究}

コエンザイム $\mathrm{Q}(\mathrm{Co} \mathrm{Q})$ はミトコンドリア内膜に存 在する電子伝達物質であり, エネルギー産生への関与 や，脂溶性の抗酸化物質としての働きが指摘されてき た（図 1). CoQ には, 側鎖のイソプレン単位の数が異 なる同族体が存在し，ヒトは CoQ10，マウスは CoQ9

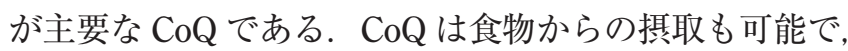
体内でも生合成されるが，加齢に伴い多くの組織中の $\mathrm{CoQ10}$ 合成量, 含有量が低下することが報告されている. 近年 $\mathrm{CoQ}$ はミトコンドリア内膜だけではなく, 細胞 膜，ゴルジ体，リソゾームなどに，また血液中では リポタンパク質中に分布しており, 多様な機能を持つ ことが報告されていることから, サプリメントとしての 効果が期待されている. CoQには酸化型 (ubiquinone： CoQ）と還元型（ubiquinol：CoQH2），およびその中 間型が存在するが，生体内では還元型として作用する ことがほとんどのため, CoQH2 は CoQ よりも摂取効 果が強いと考えられている.

SAMP1 マウスに CoQ10H2 の混餌を継続投与（250〜 $375 \mathrm{mg} / \mathrm{kg} / \mathrm{day})$ すると, 通常餌群と比較して促進老 化 (老化度評点, 過酸化脂質, 酸化タンパク質, 酸化 障害 DNA 量など）の有意な遅延や，加齢性難聴の進 行の抑制などの効果が認められたが，寿命の延長は観 察されなかった (9)。 その作用機構としては, CoQ10H2 の投与が細胞内 cAMP 濃度を増加させ, 長寿遺伝子と される Sertuin1 (SIRT1) と Sertuin3 (SIRT3)、ミトコ ンドリア機能調節遺伝子である peroxisome proliferatoractivated receptor coactivator $1 \alpha$ (PGC-1 $\alpha)$ の増加を招 き, ミトコンドリアのエネルギー産生や抗酸化能力 が活性化されることが示された. CoQ10H2 の健康増 進効果は II 型糖尿病のモデルマウスである KK-Ay マ ウスやヒト肝がん細胞 (HepG2), ヒト胎児内皮細胞
（HUVEC）でも認められ，その作用メカニズムは細胞 内 $\mathrm{Ca}^{2+}$ の減少が cAMP 分解酵素 phosphodiesterase 4 （PDE4）の発現を減少させた結果, 増加した cAMP が 上述の反応系を誘導することが明らかになっている $(10,11)$.

SAMP8 マウスは若齢からの骨格筋量の低下が観察 されサルコペニアのモデル動物であることが報告され ている. CoQ10H2 の経口投与では骨格筋での CoQ 濃度 の増加は認められないが, SAMP8 マウスへ CoQ10H2 と投与と同時に軽度の運動を付加すると，運動による 筋肉量の増大効果と CoQ10によるミトコンドリア機 能の活性化によるストレス軽減効果によって, 筋力低 下を予防できる可能性が報告されている(12). 筆者達 の解析では, CoQ10の経口摂取では, 肝臓や内皮細胞 での CoQ10 の増加が顕著で, 脂肪, 心筋, 骨格筋では 2 倍程度に増加, 脳などの臟器ではほとんど増加しな い.このような結果から, CoQ10の効果は肝臟への効 果が大きいと考えている．また脳への効果を望む場合 は, 化学構造や, 投与方法を工夫する必要がある.

2）老化アミロイドーシス研究

アミロイドーシスとはタンパク質が $\beta$ シート構造に 富む微細線維（アミロイド線維）を形成し, 主として 細胞外に沈着する疾患の総称である. 突然変異, 過剩 産生, 断片化, 加齢などが原因となり, タンパク質が 生理的な構造から $\beta$ シート構造に富む構造に変化した 結果, 凝集・重合して線維を形成し, 組織障害を引き 起こす。よく知られる例としてアミロイド $\beta(\mathrm{A} \beta)$ の 蓄積に起因するアルッハイマー病 $(\mathrm{AD})$ ， トランスサ イレチンが沈着する家族性アミロイドポリニューロパ チー（FAP）や全身性老化アミロイドーシス（SSA）, 病原性構造プリオンタンパク質に起因する牛海綿状脳 症（狂牛病）などがあり, 現在までにヒトでは 36 種の アミロイドタンパク質とアミロイドーシスが報告され ている(13)，それぞれのアミロイドーシスの病態は多 彩であるが, アミロイド形成機構や臓器沈着機構など

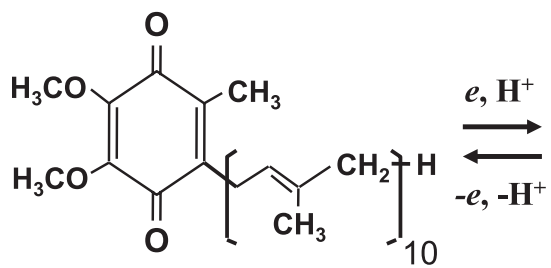

酸化型 $(\mathrm{CoQ10})$ Ubiquinone-10<smiles>COc1c(O)c(C)c(C(C)(C)C=CCC=O)c(O)c1OC</smiles>

還元型 $(\mathrm{CoQ10H2})$ Ubiquinol-10 
には共通のメカニズムが存在すると考えられている. 多くのアミロイドーシスでは年齢が重要な危険因子で あり, また $\mathrm{AD}$ やSSA は重篤かつ普遍的な加齢疾患で あるので, 高齢者の増加に伴いアミロイドーシス患者 数も今後上昇することが予測されている。モモデル動物 を用いて，これらの共通のメカニズムが解明されれば, その予防法や治療法に大きく貢献することが期待される.

筆者らのグループは SAMP1 マウスでは, 高密度血 清リポタンパク質 (HDL) のアポタンパク質の一つで ある apolipoprotein A-II（ApoA-II，遺伝子名はApoa2） がアミロイド線維を形成し，腸，舌，肝，心，腎，脾， 皮虐, 血管, 肺などの, 脳実質を除く全身臟器の細胞 外へ沈着することを明らかにした（AApoAII アミロイ ドーシス) (14)。マウスの Apoa2 遺伝子には 7 つの対 立遺伝子が存在し, C 型対立遺伝子 $\left(A p o a 2^{c}\right)$ を持つ マウス系統では, 特に重篤な AApoAII アミロイドーシ スを発症する (15)。A 型の ApoA-II $\left(A p o a 2^{a}\right)$ をもつ マウス系統でも高齢マウスではAApoAIIアミロイドー シスは比較的軽度に沈着するが, $\mathrm{F}$ 型 $\left(A p o a 2^{f}\right)$ を持つ 系統ではほとんど沈着しない. SAMP1，SAMP10は C 型, SAMP8，C57BL6 はA 型, SAMP6, SAMR1 は $\mathrm{B}$ 型の ApoA-II を持つ. Apoa $2^{c}$ を正常老化の SAMR1 の遺伝背景へ導入したコンジェニックマウス (R1-P1. Apoa $\left.{ }^{c}\right)$ では, AApoAII アミロイドーシスの自然発症が SAMP1 と比較して遅延することから，アミロイドー シスの発症に個体の老化が関与することがわかるが, 後述のアミロイド線維による伝播などの環境要因が, アミロイドーシス発症に大きな影響を与える $(16,17)$.
C 型 ApoA-II を持つマウスへの AApoAII アミロイド 線維の静脈内, 腹腔内, 胃内投与はアミロイドーシス の発症を著しく促進する。 さらにアミロイドーシスを 発症したマウスと同一ケージで飼育したマウスや， アミロイドーシスを発症している母マウスから生まれ た子マウスではアミロイドーシスが促進される。アミ ロイドーシスを発症しているマウスの糞や母乳, 唾液 中, さらに最近では骨格筋中や血液中にもアミロイド 線維が含まれていることが明らかになり，これらのア ミロイド線維を投与するとアミロイドーシスが誘発さ れることから，アミロイド線維摂取による個体間の伝 播現象が強く示唆されている(18).この伝播現象は, アミロイド線維が鋳型（seed）として作用し, 線維形 成を促進すること（seeding 現象）が原因と考えられ ており,プリオン, $\mathrm{A} \beta$ などのアミロイド線維形成にも 共通した現象である（図 2)。筆者らはアミロイドーシ ス研究には, R1-P1.Apoa2 $2^{c}$ マウスに微量のアミロイド 線維を投与してアミロイドーシスを誘発して使用して いる。このシステムを利用して, 食事制限, 運動, 線 維形成抑制ペプチドなどのアミロイドーシス予防効果 を解析している(17).

マウスでは喧嘩による創傷などの慢性炎症が，炎症 に伴う AAアミロイドーシスを引き起こす場合があり 注意が必要である. SAMP8 マウスでは加齢に伴い, $\mathrm{A} \beta$ 抗体と反応するタンパク質が脳に沈着する。この タンパク質が $\mathrm{AD}$ 患者と同様なアミロイド線維構造を とるかどうかは疑問であるが, 様々な機能性食品や物 質の老化抑制効果の指標として用いられている (19).
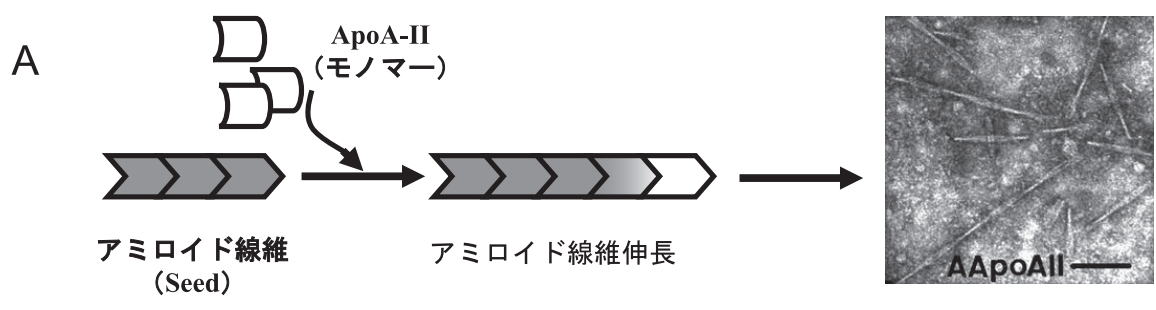

B

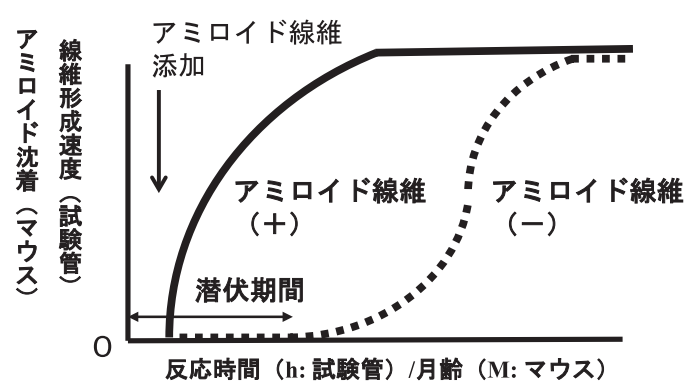

図 2 Seeding モデルによるアミロイド線維形成

(A) アミロイド線維は鋳型（seed）として, ApoA-II モノマーを末端に結合させ， $\beta$ シートに富んだ構造へ変換しながら線維が伸長していき, 組織に沈着する. (B) アミロイドタンパク質の溶液へアミロイド線維を加えると線維形成が促進され潜伏期間が消失する。 マウスではアミロ イド線維を投与すると, アミロイド沈着が促進される. 


\section{3）SAMP6 マウスを用いた骨粗鬆症研究}

骨粗鬆症は「骨量の低下, 骨組織の微細構造の変化 を特徵とし, 骨の脆弱化とその結果骨折の危険の増大 をきたした疾患」と定義される。本態は骨吸収と骨添 加作用の関係が障害されることによる，骨折に至ると 老年者の QOLを著しく低下させることより，その対 策が医学的にも急務となっている。骨粗鬆症の原因と しては(1) peak bone mass（最大骨量）に関連する要因, (2)加齢に伴う骨量減少に関連する要因，(3)閉経や性機 能低下による要因, (4)さまざまな病的状態, 薬物に関 連した要因などが考えられている。

約 1.5〜2 年齢の老齢 SAMP6 マウスにもしばしば骨 折が認められる。 マウスの骨量は 4 5 月月齢頃で最 も高くなり(これを最大骨量と称する)，その後加齢と ともに減少して行く，老齢 SAMP6 マウスにおける骨 折の原因は最大骨量が低いことであり，ヒトにおける 老人性骨粗鬆症の原因(1)に相当する (20).

ヒトやマウスの最大骨量は多因子遺伝形質であると されている，最大骨量を規定する遺伝子や分子経路の 解明は, 老人性骨粗鬆症の治療や予防の新たな分子標 的の同定に繋がる可能性がある。この目的で SAMP6 マウスを用いて大腿骨の最大骨量を規定する遺伝子群 の同定研究が行われた。 その結果, これらの遺伝子の 一つはWNT シグナル伝達系のアンタゴニストとして 働く secreted frizzled-related protein 4 タンパク質をコー ドするSfrp4 遺伝子であることが判明した(21). すな わち, SAMP6 の骨においてはS S r p 4 の発現量が充進し ているために骨芽細胞に抢けるWNT シグナル伝達が 減弱されてその増殖が抑制されるために最大骨量が抑 制される。そその後，ヒトに抏いて SFRP4 遺伝子上の 一塩基多型が閉経後女性の骨密度を規定することが報告 され(22), ヒトとマウスで最大骨量を規定する分子遺 伝学的経路の一部は共有されていることが確認された。 さらに, SAMP6 マウスを用いて, 塩化リチウムなど の投与によってWNT シグナル伝達系を活性化するこ とにより骨量が増大されることも実証された $(23,24)$. この経路を標的としない薬剤の SAMP6の骨量増大に 対する効果の検証結果も多数報告されている(25-27).

\section{4) SAMP8 マウスにおける学習・記憶障害に関する研究}

老人性認知症を代表とする学習・記憶障害を伴う疾 患患者は今後の増加が確実視されており, その発症機 構の解明や治療法・予防法の開発は益々重要となって いる.アルッハイマー型認知症モデルマウスとしては, 家族性アルツハイマー病患者に扔いて同定されたアミ ロイド前駆タンパク質 $(A P P)$ やプレセニリン $1(P S 1)$ などの遺伝子変異を導入された遺伝子改変モデルが使
用されて来た $(28)$ 。 マウスを用いた学習・記憶の評価 系には, Y 字型迷路試験 (短期記憶), 恐怖条件付け文 脈学習試験 (連合学習, 恐怖記憶), 受動回避試験 (長 期記憶), 放射状迷路試験（空間作業, 参照記憶), Morris 水迷路試験（空間学習, 空間記憶）などがある. SAMP8 マウスは，これらのいずれの評価系においても 対照 SAMR1 マウスと比較して早期（形質により 4〜 12 力月齢以降）の低下を示す (29). 脳の加齢病変とし ては, ニューロンの脱落, 海馬での PAS 陽性顆粒状構 造の増加, 脳幹と海馬でのアストログリオーシス, 脳 幹部網様体の海綿状変性などが認められる $(29,30)$. また, 神経化学的変化としては大脳皮質において過剩 リン酸化タウタンパク質産生の元進も認められる。こ れらの変化はアルッハイマー型認知症患者の脳におけ る病理変化と類似している。一方，大脳皮質と海馬に おいてAPPの部分ペプチドに対する抗体で認識され る $\beta$-LIGS と称される $\beta / A 4(A \beta)$ ペプチド様の顆粒状 構造物が認められるものの, この構造物がアミロイド を形成してはいない点や, アルツハイマー型認知症に 対する薬剤であるドネペジルなどが SAMP8 マウスに おいては有効ではないとされる点など, アルッハイマー 型認知症との違いもある. SAMP8 マウスが呈するこれ らの病態の原因は何らかの遺伝子（群）の変異である ことは確実であるが，その正体は未だ不明である. SAMP8 マウスにはA App P P I などのヒト家族性アルッ ハイマー病の原因となる遺伝子上の変異は認められない. 原因の強力な候補としては唯一, hyperpolarizationactivated, cyclic nucleotide-gated $\mathrm{K}^{+} 1$ （HCN1）をコー ドする遺伝子のポリグルタミン鎖の長さの違いの多型 が報告されている(31).SAMP8 マウスに打ける上記 の学習・記憶障害や脳病変の改善を指標として, 様々 な薬剤・化合物 (メラトニン他), 生物由来物質 (抗 $\mathrm{A} \beta$ 抗体他), 天然物（緑茶カテキン, レスベラトロー ル他）などの効果が実証されている(29).

\section{5）老化以外の病態・形質に関するトピックス}

SAMP10/TaSlc マウスは，腎臓におけるグルコース 再吸収を担うトランスポーターである sodium-glucose cotransporter-2（SGLT2）をコードする Sglt2 遺伝子の 機能岥失変異に起因する腎性糖尿病を発症する (32). 近年, SGLT2 は 2 型糖尿病治療のための新たな創薬標 的分子として注目されている(33). その作用機序は, “SGLT2 活性を阻害することで糖を尿中に積極的に排 泄させて血糖值を減少させる”というものである，既 に臨床使用されている製品もあるが, 副作用として血 中の総ケトン体の増加などが報告されている. また, 他の治療薬と SGLT2 阻害薬を併用する際の副作用の 
懸念もある．SAMP10/TaSlcマウスは内因的にSGLT2 活性を欠損し, SGLT2 阻害薬を摂取したと同等の状態 を再現していることから，このような副作用の研究な どに有用と考えられる。

駆虫薬であるイベルメクチンを投与された SAMR1 マウスが神経症状を呈して死亡したことを発端として, SAMR1，SAMP1，およびSAMP6 マウスが, 細胞毒性 を有する化合物や薬剤などの腸管腔への排出や血液脳 関門での脳内侵入の阻止などに機能しているいわゆる 多剤耐性 P- 糖タンパク質をコードする ATP-binding cassette, sub-family B, member 1a（Abcb1a）遺伝子に, レトロトランスポゾン挿入による機能衣失変異を有す ることが発見された (34)。このことは創薬の観点から 三つの点で重要である. 一点目は, $\mathrm{ABCB} 1$ の基質で ある薬剤の有効性を検証する場合, $\mathrm{ABCB} 1$ 活性を内 因性に皮失しているSAM マウスを用いることで $\mathrm{ABCB} 1$ 阻害薬の同時投与の必要性を回避できること である. 二点目として, これらのSAM マウスはイベ ルメクチン以外の様々な薬剤に対しても高い感受性を もつ可能性には逆に注意が必要である。 三点目は, 潰 瘍性大腸炎との関わりである。潰瘍性大腸炎は，大腸 粘膜へのリンパ球の浸潤によるびらんや潰瘍を主徴と する大腸の炎症性疾患であり, 患者数も増加しつつあ る疾患であるにも関わらず，その発症機序・原因の全 容はいまだに不明であり, 治療薬の開発も喫緊の課題 となっている，興味深いことに，ヒトに抏いては $A B C B 1$ 遺伝子上の一塩基置換多型は潰瘍性大腸炎の 危険因子であり (35), この変異をもつ SAMP6 マウスも 潰瘍性大腸炎を発症する(36)。このことから SAMP6 マウスはヒトと類似した潰瘍性大腸炎発症機序を有し， そのモデルとしての有用性も高いと考えられる(37).

\section{4. おわりに}

SAMP 各系統に共通する促進老化の原因（遺伝子） は何か？に関しては, 酸化ストレスへの高感受性, ミ トコンドリア機能の加齢依存的減退, DNA 傷害など が提唱されているが，まだ全容は明らかとなっていな い.また，系統特異的な老化関連疾患の発症機序，お よびその促進老化との関わりについても，これまでに 明らかとされた原因遺伝子はまだ一部に過ぎず，大部 分は未解明のままである。最近, SAM マウス系統の エクソーム解析 (38), および全ゲノム解析が行われ, 各系統に共通する，あるいは系統特異的に保有される 複数の塩基変異が同定された，今後，これらのデー夕 を詳細に解析することで，これらの塩基変異と促進老 化・老化関連疾患との関わりが明らかとなって行くと
期待される.

SAM マウスは株式会社日本エスエルシーから購入 でき, 本稿で紹介した以外にも様々な研究に使用され ている，老化促進モデルマウス（SAM）学会が設立さ れており,これらの研究成果の共有のための研究発表 会の開催，さらには SAM の品質管理・維持に関する 調查および情報の収集と提供, SAM およびその関連 研究の国際交流の推進, などの活動が行なわれてい る。これらの情報は学会が主催するホームページ (http://www.samrc.jp) からも取得できる. SAM マウ スが今後もより多くの研究者に使用されることで老化 や老化関連疾患の研究が進展し, また創薬にも貢献す ることを期待する。

著者の利益相反 : 樋口京一 (株式会社カネカ).

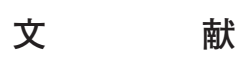

1) Longo VD, et al. Aging Cell. 2015;14:497-510.

2) Takeda T, et al. J Am Geriatr Soc. 1991;39:911-919.

3) Mounkes LC, et al. Nature. 2003;423:298-301.

4) Pendás AM, et al. Nat Genet. 2002;31:94-99.

5) Trifunovic A, et al. Nature. 2004;429:417-423.

6) Kuro-o M, et al. Nature. 1997;390:45-51.

7) Niedernhofer LJ, et al. Nature. 2006;444:1038-1043.

8) Barnhoorn S, et al. PLoS Genet. 2006;10:e1004686.

9) Tian G, et al. Antioxid Redox Signal. 2014;20:2606-2620.

10) Xu Z, et al. Sci Rep. 2017;7:8253.

11) Huo J, et al. Oxid Med Cell Longev. 2018;2018:3181759.

12) Andreani C, et al. Oxid Med Cell Longev. 2018;2018:8936251.

13) Sipe JD, et al. Amyloid. 2016;23:209-213.

14) Higuchi K, et al. J Biol Chem. 1986;261:12834-12840.

15) Kitagawa K, et al. Amyloid. 2003;10:207-214.

16) Korenaga T, et al. Am J Pathol. 2004;164:1597-1606.

17) Sawashita J, et al. Proc Natl Acad Sci U S A. 2015;112:E836-E845.

18) Ding X, et al. Exp Anim. 2018;67:105-115.

19) Katayama S, et al. J Agric Food Chem. 2016;64:4908-4913.

20) Azuma K, et al. Med Mol Morphol. 2018;51:139-146.

21) Nakanishi R, et al. J Bone Miner Res. 2006;21:1713-1721.

22) Lee DY, et al. Menopause. 2010;17:1064-1070.

23) Clément-Lacroix P, et al. Proc Natl Acad Sci U S A. 2005;102: 17406-17411.

24) Saidak Z, et al. Aging Cell. 2012;11:467-474.

25) Saidak Z, et al. J Endocrunol. 2014;223:25-33.

26) Okiura T, et al. J Musculoskelet Neuronal Interact. 2016;16:161-167.

27) Antika LD, et al. J Neutr Biochem. 2017;49:42-52.

28) Woodruff-Pak DS. J Alzheimers Dis. 2008;15:507-521.

29) Cheng XR, et al. Ageing Res Rev. 2014;13:13-37.

30) Akiguchi I, et al. Neuropathology. 2017;37:293-305.

31) Akbor MM, et al. Biochem Biophys Res Commun. 2013;441:25-30.

32) Unno K, et al. Biochem Biophys Res Commun. 2014;454:89-94.

33) Wanner C, et al. Diabetologia. 2018;461:2134-2139.

34) Zhang G, et al. Exp Anim. 2008;57:413-417.

35) Petryszyn PW, et al. Adv Clin Exp Med. 2018;27:1459-1463.

36) Tanaka S, et al. Senescence-Accelerated Mouse (SAM): An animal model of senescence. Elsevier; 2004. p. 167-173.

37) 森政之. BIO Clinica. 2015;30:76-80.

38) Tanisawa K, et al. BMC Genomics. 2013;14:248. 


\title{
The senescence-accelerated mouse as a model for geriatrics and aging biology
}

\author{
Masayuki Mori ${ }^{1)}$, Keiichi Higuchi ${ }^{2)}$ \\ ${ }^{1)}$ Department of Advanced Medicine for Health Promotion, Institute for Biomedical Sciences, Interdisciplinary Cluster for \\ Cutting Edge Research, Shinshu University \\ ${ }^{2)}$ Department of Biological Sciences for Intractable Neurological Diseases, Institute for Biomedical Sciences, \\ Interdisciplinary Cluster for Cutting Edge Research, Shinshu University
}

\begin{abstract}
Rapid expansion of aged population is predicted worldwide. To cope with problems expected from this situation and extend the period of active and healthy life of people as much as possible, it is important to elucidate not only the biological mechanisms of "aging", but also the etiology of various "agerelated diseases". To attain this goal, extensive studies using excellent animal models are indispensable. Senescence-accelerated mouse (SAM) is a series of inbred mouse strains that includes SAMP1, SAMP6, SAMP8, SAMP10, and SAMR1. SAMP strains exhibit accelerated senescence and short lifespan. In addition, each strain shows specific age-related disease phenotypes which are similar to symptoms observed in humans, such as senile amyloidosis (SAMP1), senile osteoporosis (SAMP6), and age-dependent deficits in learning and memory (SAMP8), making SAM mice useful for an aging research. In this review, we introduce the characteristics and application of SAM in geriatrics and aging biology.
\end{abstract}

